\title{
Does Audit Quality Affect Client Satisfaction of Non Profit Organization in Indonesia?
}

\author{
Mika Marsely* \\ Accounting Department \\ POLINEMA \\ Malang, Indonesia \\ *mika.marsely@polinema.ac.id
}

\begin{abstract}
The previous research addresses the relationship among audit quality and client satisfaction in the private sector and government sector. This study develops such research to non profit organization that focused on accelerating poverty reduction and expanding employment opportunities through community empowerment in Indonesia, where audit quality had been questioned. The authors use non-simultaneous regression models to analyses the factors of perceived audit quality and client satisfaction on each of 12 dimensions of audit quality by Carcello et al exclude audit committee involvement. The result from 293 non-profit organizations that were surveyed showed that auditor expertise and responsiveness to client needs are positively associated to client satisfaction. In contrary, this study found that competence, independence, due care, commitment to quality, conduct of field work, high ethical standards and auditor skepticism were not associated to client satisfaction despite these factors are the common requirement of audit conduct. Overall, we can conclude that the role of communication and relationship is very important to client satisfaction.
\end{abstract}

Keywords: audit quality, client satisfaction, non profit organization

\section{INTRODUCTION}

Community Development Board (CDB) is a non-profit organization (NPO) formed by the Indonesian government. This organization were aims to accelerating poverty reduction and expanding employment opportunities both in rural and urban areas through the community empowerment. Starting in 2012, the Indonesian Government requires CDB to be audited by independent auditors in object to increase the accountability of $\mathrm{CDB}$ as a fund management institution from the government. The source of $\mathrm{CDB}$ funds comes from government loans such as World Bank, Asian Development Bank, government grants, and donations. Therefore, NPOs are accountable to the public, who finances these loans, donations and grants [1].

Accountability is a complex and multidimensional concept. Connolly \& Dhanani distinguish between accountability towards resource providers (upward accountability) and accountability towards beneficiaries (downward accountability). Even though financial reporting does not report on the effect of NPOs' strategies and programs for beneficiaries, they do concede assessing NPOs' financial position as well as the sources and uses of NPOs' funds [2,3]. Reheul et al revealed that NPOs' financial statements and audit reports are used by different stakeholders [4]. Before making a contribution, donors consider financial ratios based on NPOs' financial statements [5]. Further, donations, government grants and debts are revealed to decrease after an NPO receives a going-concern opinion [6].

From Belgia, Mortier and Baten found that resource providers and providers of labor are the most frequent users of NPOs' financial statements [7]. Meanwhile Verbruggen et al revealed that governments rely on NPOs' financial statements for funding and supervisory purposes [8]. Vesterlund describes various motives for giving. One motive for resource providers to contribute to an NPO is their concern about the NPO's mission, project or program [9]. Supposedly, resource providers assess the realization of their motive (for instance the achievement of the NPO's mission) among others by analyzing the financial health and going concern of the NPO using the audited financial statements and audit reports.

The concept of audit quality is complex and difficult to measure directly [10]. In the private sector, Carcello et al has identified 12 audit engagement attributes related to audit quality and [11]. Behn et al use the 12 perceived audit quality by Carcello et al with focusing on the effect of audit quality to client satisfaction [12]. Samelson et al do the similar research in the local government sector [13]. Since private and governments organization differ substantially from non-profit organizations in certain respects, it is not clear that findings from the private and government sector will generalize to nonprofit sector. Thus, we adapt Samelson et al findings to investigate the relationship between audit quality and auditee satisfaction of non-profit organizations. So the purpose of this study was to investigate the relationship between audit quality and auditee satisfaction of non profit organization in Indonesia between 2015-2017. 


\section{METHODS}

Our survey questions related primarily to the audit team rather than the audit firm as previously noted by Carcello et al that audit quality factors are more often associated with the specific audit team than the audit firm. All opinion items related to audit attributes were measured on 5-point Likert scales (strongly agree - strongly disagree). Data collection methods used in this study are using a questionnaire. As a complement to the data, researchers will conduct interviews and documentation in the form of audit results data that has been published by Public Accountant Firm and other data relevant to the research. From the answers obtained from the next respondent will be analyzed using multiple linear regression. Multiple linear regression analysis is used to answer the hypothesis in this study. Multiple linear regression analysis were used for measuring the strength of the relationship between two or more variables, it also shows the direction of the relationship between the dependent variable and the independent variable.

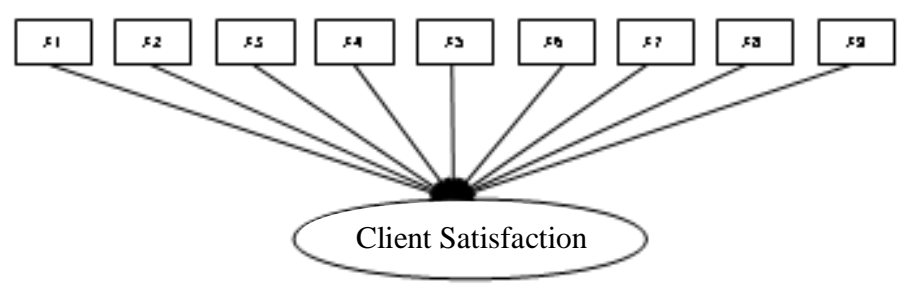

Fig. 1. Conceptual framework.

\section{RESULTS AND ANALYSIS}

The result of the analysis showed in the table below:

TABLE I. COEFFICIENT ${ }^{\mathrm{A}}$

\begin{tabular}{|c|c|c|c|c|c|}
\hline \multirow{2}{*}{ Model } & \multicolumn{2}{|c|}{$\begin{array}{c}\text { Unstandardized } \\
\text { Coefficients }\end{array}$} & \multirow{2}{*}{$\begin{array}{c}\begin{array}{c}\text { Standardized } \\
\text { Coefficients }\end{array} \\
\text { Beta }\end{array}$} & \multirow{2}{*}{$\mathbf{t}$} & \multirow{2}{*}{ Sig. } \\
\hline & $\boldsymbol{B}$ & $\begin{array}{c}\text { Std. } \\
\text { Error }\end{array}$ & & & \\
\hline 1 (Constant) & -27.665 & 10.529 & & -2.628 & .015 \\
\hline $\mathrm{x} 1$ & 1.036 & .344 & .409 & 3.013 & .006 \\
\hline $\mathrm{x} 2$ & .834 & .350 & .385 & 2.382 & .026 \\
\hline $\mathrm{x} 3$ & .362 & .225 & .226 & 1.607 & .122 \\
\hline $\mathrm{x} 4$ & .239 & .240 & .138 & .995 & .330 \\
\hline $\mathrm{x} 5$ & .052 & .209 & .038 & .249 & .806 \\
\hline $\mathrm{x} 6$ & .323 & .168 & .292 & 1.924 & .067 \\
\hline $\mathrm{x} 7$ & .188 & .216 & .112 & .717 & .481 \\
\hline $\mathrm{x} 8$ & -.121 & .302 & -.060 & -.402 & .692 \\
\hline $\mathrm{x} 9$ & .498 & .286 & .281 & 1.739 & .096 \\
\hline
\end{tabular}

\section{A. Industry Expertise and Client Satisfaction}

Understanding of the client industry is stated to have an effect on client satisfaction. Understanding of the client industry is an important determinant of audit quality because the auditor can find out the risks, opportunities and accounting practices for the client industry obtained during audit work [14]. Boon et al found that the financial and internal auditors of local governments in the New South Wales region were more satisfied when the audit was carried out by someone who was an expert or specialist in the client industry.
The results of this study are consistent with research conducted by Carcello et al, Bhen et al, Samelson et al and Boon et al which states that understanding the client industry is an audit quality attribute that most influences client satisfaction. Besides being able to make audits more quality, understanding the client industry is also useful to provide input so that clients operate more [15]. But a slightly different thing is stated by Iskandar et al in his research findings that clients do not specifically refer to the auditor's understanding of the industry in determining their satisfaction [16]. Clients emphasize that they will feel more satisfied when the field audit is carried out adequately and also the audit team has high ethical standards and extensive knowledge of accounting and auditing.

\section{B. Responsiveness to Client Needs and Client Satisfaction}

Responsiveness to client needs is stated to affect client satisfaction. In accordance with the opinion of Johnson and Lyss that one of the factors that make clients make their choices on the auditor is because the auditor's sincerity pays attention to client needs [17]. The results of Johnson and Lyss research are reinforced by the evidence that there is a sense of satisfaction by the auditors because of the attention and contribution of suggestions for improvement from the auditor on matters that are problematic and cannot yet be resolved.

The results of this study are consistent with the results of Carcello et al, Bhen et al, Samelson et al, Boon et al and Iskandar et al who found that responsiveness to client needs was wrong. one main factor that determines client satisfaction. But what is slightly different is that in Carcello et al research audit quality factors that most influence client satisfaction are auditor responsiveness to client needs and involvement of audit firm leaders, whereas in this study it was found that the most influential factors on client satisfaction are understanding of the client industry and auditor responsiveness to client needs. Bhen et al in his research also stated that client expectations are actually not just giving opinions, but rather they will be more satisfied when they get more benefits from the auditor. Bhen et al added that in fact clients also did not always want to ask the auditor. They expect auditors to be able to provide advice and be able to be like business partners when conducting audits.

Samelson et al. Described the auditor's responsiveness factor more responsive to client's planning needs. Boon et al also stated that a good working relationship between the auditor and the client will provide good cooperation, an effective and efficient audit process as well as for the audit firm, it is also easier to provide suggestions for improving the operation practices and financial statements of clients.

\section{Technical Competence and Client Satisfaction}

Competency attributes are stated to have no significant effect on client satisfaction. In accordance with the opinion of Bhen et al that there are 5 things that form the basis of the audit, namely the existence of technical competence, independence, caution, commitment to quality and ethical standards. But these 5 components are not directly related to client satisfaction such as other audit quality components. These five components are used as collateral for quality audits. 
The results of this study are consistent with the research conducted by Bhen et al, Samelson et al, and Iskandar et al that auditor competence has no effect on client satisfaction. Samelson et al found that although the audit team as a whole has adequate technical competence but its contribution is small to audit quality perceived by the client. The fact that CDB are less aware of the importance of auditing, and auditing is more due to the fact that the abortion is reinforcing the fact that $\mathrm{CDB}$ are less concerned about the quality of audit services provided by the auditor. The same as stated by Samelson et al that competency attributes have little influence on client satisfaction.

On the contrary, these findings contrast with the findings of Boon et al which states that competency has a positive effect on client satisfaction. According to Boon et al, audit staff who have technical competence as certified accountants or public accountants are certainly familiar with accounting and auditing standards and of course are also better able to detect material misstatements. Staff of financial experts and internal auditors (clients) who were respondents stated that overall they would feel more satisfied when the audit team had adequate technical competence. Because adequate technical competence is part of overall quality audit services.

\section{Independence and Client Satisfaction}

The independence attribute is stated to have no significant effect on client satisfaction. According to Bhen et al, even though the auditor who carried out the audit had been independent but had no effect on the satisfaction of his client, because the client was more pleased if the auditor could be invited to two-way communication. During this time, the community, especially members of the CDB and its administrators, do not yet have more awareness of the importance of the audit. Until now there are still many CDB that conduct audits due to the abortion factor. From the findings above, it can be concluded that the high or low level of auditor independence does not have an influence on the CDB satisfaction because the client feels less of an interest and awareness of the audit.

The results of this study are consistent with the results of the study of Bhen et al, and Samelson et al who found that the independence variable had no relationship or influence on client satisfaction. In his research Samelson et al found that in the client's view, independence actually had little or no influence during the field audit. Different research results are found by Boon et al and Iskandar et al where independence has a positive influence on client satisfaction. Iskandar et al found that clients perceive independence directly reflects audit quality. While Boon et al found that auditors who have independence will provide higher audit quality. Therefore, the client perceives that the overall audit will be quality if the auditor has independence.

\section{E. Due Professional Care and Client Satisfaction}

Attributes of the audit team's cautious attitude are stated to have no significant effect on client satisfaction. In accordance with Bhen et al's statement that the audit team's cautious attitude is not directly related to client satisfaction such as other audit quality components. The audit team's cautious attitude is only used as a guarantee of a quality audit. This study is in accordance with the results of the study of Bhen et al who found that the variable attitudes of the audit team had no influence on client satisfaction. Bhen et al stated that, on the contrary, the results of this study contradict the results of Boon et al research which states that the audit team's caution influences client satisfaction. According to Boon et al, clients feel more satisfied with the quality of audit services as a whole when the auditor has a cautious attitude. According to the client, the implementation of the audit with a cautious attitude is certainly carried out in accordance with accounting and auditing standards. This will provide higher audit quality, a more credible audit opinion, and reduce the risk of Public Accountant Firm to be involved in the case of justice in proving compliance with the client's compliance / obligations with the law.

\section{F. CPA Firms Commitment to Quality and Client Satisfaction}

The attributes of audit firm's commitment to audit quality are stated to have no significant effect on client satisfaction. The results of this study are consistent with the results of the study of Bhen et al which states that the attributes of audit firms commitment to audit quality do not directly affect client satisfaction. According to him, this attribute is used as a guarantee of quality audits. Conversely, the results of this study are not consistent with the research conducted by Boon et al and Iskandar et al who found that audit firms commitment to quality has a positive effect on client satisfaction. Boon et al found that audit firms that has a culture of maintaining quality is presumed to provide high-quality audits. This is reflected in the audit team deployed to actually carry out quality audit practices because the culture is embedded in them.

\section{G. Conduct of Field Work and Client Satisfaction}

The attributes of field audit implementation do not significantly influence client satisfaction. Bhen et al stated that the implementation of appropriate field audits would increase client satisfaction. This lack of influence is due to a number of clients who are less satisfied with the field audit conducted by the audit team, such as the auditor changing in the process of audit and unadequate sampling process. In general, the auditor examine the bank account security system, do cash in hand inspection, but the examination of the authorization of cash receipts and disbursement transactions and the system of financial records and reports is not detailed. The results of this study are not consistent with research conducted by Samelson et al, Boon et al and Iskandar et al who found that the implementation of field audits had a positive influence on client satisfaction. Samelson et al found that clients were more pleased when the audit team evaluated their accounting and internal control systems.

\section{H. Ethics, Accounting and Auditing Knowledge and Client Satisfaction}

Attributes of high ethical standards from the audit team are stated to have no effect on client satisfaction. Bhen et al also stated that the audit team's cautious attitude was not directly related to client satisfaction such as other audit quality components. The audit team's cautious attitude is only used as 
a guarantee of a quality audit. The results of this study are not consistent with the results of Boon et al and Iskandar et al who found that high ethical standards influence client satisfaction. Boon et al found that audit teams that have high ethical standards will be better able to provide quality audit services. This is reflected in the ability to detect and report the findings of errors and irregularities as well as the integrity of auditors as well as being safer because they cannot be compromised during the audit process.

\section{Skeptical Attitude of CPA Personnel and Client Satisfaction}

The attribute of skepticism of the audit team is stated to have no significant influence on client satisfaction. According to Bhen et al, clients will feel dissatisfied if the auditor who does his job puts high suspicion on his client. The results of this study are consistent with the research of Samelson et al and Iskandar et al who found that there was no positive influence between the audit team's skepticism on client satisfaction. Samelson et al found that audits conducted in the government sector actually have more tolerance compared to private sector audits. Therefore skepticism has little influence on client satisfaction. These findings are actually slightly contradictory to auditing standards that emphasize the auditor's skepticism to ensure a quality audit. Iskandar et al found that in fact clients did not expect auditors to be skeptical to give satisfaction to them, but enough to conduct appropriate field audits and have a more careful attitude during the audit.

\section{Discussion}

This research found that the auditor expertise and responsiveness to client needs were positively associated withclient satisfactions. We can conclude that communications and relationships is very important to client satisfaction. Expertise were viewed as an important component of audit quality. As expected, auditor's responsiveness to the scheduling requirements of the auditee is recognized as a component of audit quality, as is the exercise of professionalism. The finding of technical competence, independence, due professional care, CPA firm commitment to quality, conduct of fieldwork, ethics, accounting and auditing knowledge, and skeptical attitude of CPA personnel were negatively associated with client satisfaction were interesting. This result does not indicate that the auditor were lack quality, this may related with the auditee perception that these factors are common requierement of audit conduct that auditor must have. The limitations of this research is related to the research methodology. As typical of every survey study, it is possible that the respondents misinterpreted survey questions or interpreted certain answer options differently, causing measurement bias. We did not attempt to gain confirmatory (or other) insights by means of face-to-face interviews. Future research could conduct qualitative research to overcome these problems and could for example adopt a more sector specific approach.

\section{Conclusion}

This article develops the previous research in audit quality and client satisfaction to the non-profit organization. We also use 12 perceived audit quality found by Carcello et al which are: industry expertise and client satisfaction, responsiveness to client needs and client satisfaction, technical competence and client satisfaction, independence and client satisfaction, due professional care and client satisfaction, CPA firms commitment to quality and client satisfaction, conduct of field work and client satisfaction, ethics, accounting and auditing knowledge and client satisfaction, and skeptical attitude of CPA personnel and client satisfaction with the exception of auditor experience, audit-firm management involvement and conducting field work. This research found that the most factor affecting client satisfaction are auditor expertise and responsiveness to client needs. The limitations of this research is related to the research methodology. As typical of every survey study, it is possible that the respondents misinterpreted survey questions or interpreted certain answer options differently, causing measurement bias. We did not attempt to gain confirmatory (or other) insights by means of face-to-face interviews. Future research could conduct qualitative research to overcome these problems and could for example adopt a more sector specific approach.

\section{REFERENCES}

[1] M.H. Yetman and R.J. Yetman, "The Effects of Governance on the Accuracy of Charitable Expenses Reported by Nonprofit Organizations", Contemporary Accounting Research, vol. 29, no. 3, pp. 738- 767, 2012.

[2] C. Connolly and A. Dhanani, "Investigating the Discharge of Accountability by UK Charities through Narrative Information", Research Report No. 109, Association of Chartered Certified Accountants, London, pp. 1-80, 2009.

[3] L. Torres and V. Pina, "Accounting for Accountability and Management in NPOS: A Comparative Study of Four Countries: Canada, the United Kingdom, the USA and Spain.", Financial Accountability and Management, vol. 19, no. 3, pp. 265-285, 2003.

[4] A.M. Reheul, T.V. Caneghem, and S. Verbruggen, "Nonprofit Organizations' Choice In Favor Of A Sector Expert Auditor: A Study Of Behavioral Choice Criteria", Journal of Public Budgeting, 2015.

[5] J.M. Trussel and L.M. Parsons, "Financial Reporting Factors Affecting Donations to Charitable Organizations.", Advances in Accounting, no. 23, pp. 263-285, 2008.

[6] N.C. Feng, Economic Consequences of Going Concern Audit Opinions in Non-Profit Organizations. [Online]. Retrieved from http://ssrn.com/abstract=2014803, 2011.

[7] T. Mortier and T. Baten, Empirisch Gebruiksonderzoek van Jaarrekeningen van Verenigingen Zonder Winstoogmerk Empirical research on the use of financial statements of nonprofit organizations, Master Thesis Ghent, Belgium: University of Ghent, 2010.

[8] S. Verbruggen, A.M. Reheul, T.V. Caneghem, J. Dierick, C. Vanhee, and J. Christiaens, Het Bedrijfsrevisoraat in de Verenigingssector-Le Révisorat d'Entreprises dans le Secteur Associatif : The external financial audit in the nonprofit sector. Antwerp, Belgium: Maklu, 2011.

[9] L. Vesterlund, Why do People Give? In R. Steinberg and W.W. Powell (Eds.), The Nonprofit Sector. New Haven, NJ: Yale University Press, 2006.

[10] L.E. DeAngelo, "Auditor Size and Audit Quality", Journal of Accounting and Economics, vol. 3, no. 3, pp. 183-200, 1981.

[11] J.V. Carcello, R.H. Hermanson, and N.T. McGrath, "Audit Quality Attributes: The Perceptions of Audit Partners, Preparers, and Financial Statement Users", Auditing: A Journal of Practice \& Theory, vol. 11, no. 1 , pp. 1-15, 1992 . 
[15] R. Widagdo, Analisis Pengaruh Atribut-Atribut Kualitas Audit Terhadap Kepuasan Klien. Semarang: Program Pasca Sarjana Magister Akuntansi Universitas Diponegoro, 2002.

[12] B.K. Behn, J.V. Carcello, D.R. Hermanson and R.H. Hermanson, "Client Satisfaction and Big 6 Audit Fees," Contemporary Accounting Research, vol. 16, no. 4, pp. 587-608, 1999.

[13] D. Samelson, S. Lowensohn and L.E. Johnson, "The Determinants of Perceived Audit Quality and Auditee Satisfaction in Local Government", Journal of Public Budgeting, Accounting \& Financial Management, vol. 18, no. 2, pp. 139-166, 2006.

[14] K. Boon, J. McKinnon, and P.Ross, "Audit Service Quality in Compulsory Audit Tendering, Preparer Perceptions and Satisfaction", Accounting Research Journal, vol. 21, no. 2, 2008.

[16] T.M. Iskandar, M.M. Rahmat, and H. Ismail, "The Relationship Between Audit Client Satisfaction and Audit Quality Attributes: Case of Malaysian Listed Companies", Int. Journal of Economics and Management, vol. 4, no. 1, pp. 155-180, 2010.

[17] W.B. Johnson and T. Lys, “ The Market for Audit Service: Evidence from Voluntary Auditor Changes", Journal of Accounting and Economics, pp. $281-308,1990$. 